I Fundação Oswaldo Cruz (Fiocruz), Programa de Pós-Graduação em História das

Ciências e da Saúde, Rio de Janeiro, RJ, Brasil

robert.wegner@fiocruz.br

https://orcid.org/oooo-oooI-685I-9907

Robert Wegner'

\title{
MÁRIO DE ANDRADE, SUAS CARTAS E NÓS: UMA DOENÇA QUE NÃO EXISTE MAIS E A DOENÇA DOS NOSSOS DIAS ${ }^{1}$
}

Estes tempos de ameaça da covid-ı9, em que fomos levados a buscar o isolamento social, podem se constituir em um momento oportuno para pensar em dois aspectos da produção epistolar de Mário de Andrade: a carta como um veículo crucial no cultivo da amizade e a doença como um fenômeno que ronda a vida moderna. No primeiro caso, por meio de um veículo que pressupõe distância espacial, o escritor paulista não apenas construiu parte de sua contribuição intelectual e artística, como cultivou seus laços de amizade e modelou sua identidade, mantendo extensa correspondência com um grande número de escritores e artistas brasileiros (Miceli, 2009). Como notou Ricardo Benzaquen de Araújo (20I9: 4IO-4I2), Mário de Andrade fez isso de modo peculiar e - nas cartas trocadas com Carlos Drummond de Andrade, por exemplo - não se ateve às "regras da conveniência e do decoro" que balizam a "retórica epistolar". Ele se pautou, antes, pela mais pura "autenticidade", sublinhando a todo momento as "dimensões mais singulares e enfáticas da sua personalidade". As cartas redigidas por Mário de Andrade eram como um sismógrafo a registrar as menores variações do seu espírito.

No segundo caso, em meio a revelações pessoais e confissões, Mário de Andrade fazia descrições detalhadas de doenças, dores físicas e mesmo pequenos procedimentos cirúrgicos. Tão grande era a persistência dessas referências que o próprio Drummond (2002) veio a fazer o levantamento e o registro minucioso das passagens nas quais o amigo se referia a suas condições de 
saúde. A doença que Mário de Andrade descreveu de modo recorrente não apenas nas cartas dirigidas a Drummond, mas também a Manuel Bandeira, Ribeiro Couto e ainda mais especialmente Pio Lourenço Corrêa foi a "neurastenia". Citando uma crise nervosa sofrida em I9I3, aos quase 20 anos de idade, quando, em um acidente em uma brincadeira na escola, seu irmão mais novo, Renato, bateu a cabeça e morreu, Mário de Andrade descreveu para mais de um amigo a doença incurável que passou a o acompanhar: a "neurastenia aguda" - que sempre lhe inspirou cuidados, como técnicas para combater a insônia e períodos de descanso fora da cidade de São Paulo. Em seus depoimentos nota-se a importância das consequências da morte do irmão no que diz respeito a suas relações familiares, sua experiência com a doença, bem como sua identidade como escritor.

Neste artigo sugiro que a doença dos nervos desempenhou um papel importante na construção da identidade de Mário de Andrade. Ao se identificar como neurastênico - uma categoria nosológica para uma doença nervosa que vigorava então -, o escritor se reconheceu como alguém que está sempre com "os nervos à flor da pele", em vez de assumir uma atitude blasé perante o mundo e seus amigos. Suas relações, mediadas pelas cartas, seriam cultivadas de forma intensa e sem filtros, o que, por outro lado, exigia por parte de Andrade o emprego de técnicas para acalmar os nervos e períodos de descanso completo da vida na grande cidade. Por fim, sugiro que esse modo de utilizar as cartas, evitando a "retórica epistolar" do decoro e a substituindo pela "autenticidade", além do que pode revelar sobre Mário de Andrade, ajuda-nos, em um tempo de distanciamento espacial, a renovar o modo pelo qual exercemos nossa sociabilidade por meio das redes sociais e correspondências eletrônicas.

\section{O SIGNIFICADO DA DOENÇA NO MUNDO CONTEMPORÂNEO}

Este momento em que uma doença passou a fazer parte do nosso cotidiano, quando desde questões mais comezinhas, como a compra em um supermercado, até reflexões políticas de ordem mais geral, como o comportamento do chefe do Poder Executivo, são vincadas pela existência do vírus SarsCov-2, é um bom momento para refletir sobre a concepção de doença que vigora na medicina desde a virada do século XIX para o XX, permeando a vida nas sociedades contemporâneas. Segundo o historiador da medicina norte-americano Charles Rosenberg, o diagnóstico de uma doença ocupa lugar crucial no modo pelo qual as pessoas pensam sobre si mesmas e sobre os outros. Por ser tão naturalizado, não percebemos esse papel que, na realidade, não tem mais do que I50 anos. Na medicina anterior à bacteriologia, as doenças costumavam ser interpretadas a partir do sofrimento individual e, na verdade, existiam tão somente enquanto indivíduos estivessem doentes. Nas palavras de Rosenberg (2002: 242), "o corpo sempre estava em risco, mas um risco configurado em termos idiossincráticos, fisiológicos, multicausais e contingentes”. ${ }^{2}$ 
Na virada do século XIX para o XX, ao lado da percepção trazida pelas teorias da bacteriologia de que eram ocasionadas por seres microscópicos, cada uma das doenças passou a ser compreendida como algo existente fora do corpo (cf. Rosenberg, 2002: 242). Assim, para o autor, "essas teorias disseminaram metaforicamente a noção mais abstrata da entidade doença como um tipo ideal abstraído de suas manifestações particulares. Uma doença legitimada possuía tanto um curso clínico característico quanto um mecanismo que lhe era próprio"3 (Rosenberg, 2002: 243).

Em outras palavras, as doenças específicas passaram a ter sua própria história, que podia ganhar uma narrativa. Hoje, na pandemia, esse fenômeno parece ficar bastante explícito, pois essa noção de doença nos acompanha ao buscarmos notícias nos jornais e nas redes sociais. Não apenas acompanhamos os dados estatísticos sobre a propagação da doença covid-I9 em diferentes países, estados, cidades, como também queremos entender como o vírus SARSCov-2, em si, como um ser vivo, se comporta. Somos instados a nos perguntar quanto tempo ele vive fora do corpo humano, como ele morre e como evitá-lo.

Por outro lado, o poder das doenças não repousa em sua qualidade platônica, mas em sua capacidade de adquirir tessitura social e circunstancialidade, o que ocorre a partir do evento do "diagnóstico". Nesse plano, o momento em que uma pessoa é diagnosticada por um médico como portadora de uma doença constitui uma ruptura na sua narrativa de vida, e as características específicas da doença passam a constituir um dado que se impõe ao indivíduo (cf. Rosenberg, 2002: 250).

Assim, por um lado, as doenças se tornaram específicas, e cada uma delas passou a ter sua narrativa particular fora dos corpos das pessoas, de forma abstrata. Por outro lado, elas ganham encarnação social com o ato do diagnóstico. A partir desse momento, uma doença estabelece uma ruptura na história de vida de um indivíduo e passa a fazer parte da sua identidade e de suas relações com os outros. A doença passa a fazer parte do cotidiano. Assim se deu com Mário de Andrade.

\section{NEURASTENIA E IDENTIDADE}

Mário de Andrade costumava se referir tanto a sua crise de I9I 3 quanto à doença nervosa que passou a o acompanhar como neurastenia aguda. Segundo Rafaela Zorzanelli (2010), a neurastenia foi uma doença específica que não teve vida longa. Sua narrativa teve início nos últimos decênios do século XIX e se encerrou nas primeiras décadas do século seguinte, em boa medida por causa da psicanálise e suas explicações de caráter não fisiológico. Pouco se ouviu falar de neurastenia no meio médico a partir da década de I930 (cf. Zorzanelli, 20ıо: 44I). Descrita pela primeira vez em I869, por George M. Beard, nos Estados Unidos, em um momento de intensa expansão econômica do país, a neurastenia se tornou uma doença própria da civilização, quando a constituição nervosa do 
indivíduo deixava de processar todos os impulsos e influxos da vida nas grandes cidades (cf. Zorzanelli, 20I0: 432). Conforme apontava Beard (apud Zorzanelli, 20I0: 433), "a anemia é para o sistema vascular o que a neurastenia é para o sistema nervoso". Se a anemia envolvia falta de sangue, a neurastenia significava carência de "energia nervosa".

Assim, na argumentação de Zorzanelli (2010: 436-437), resulta que,

Por herdarem uma constituição fraca dos nervos, os neurastênicos não poderiam ser curados, e por isso, deviam ser educados para viver de acordo com suas insuficiências ou neutralizá-las. Sobre a disposição hereditária incidia a necessidade de aumentar os esforços da vontade do indivíduo para superar os efeitos particulares da sua natureza.

Ao estudar a noção de indivíduo entre finais do século XIX e meados do XX, o antropólogo Luiz Fernando Dias Duarte discute a centralidade ocupada pela categoria nervosismo. Segundo o autor, o "sistema nervoso" consistia na "mais alta articulação da pessoa, lugar de todos os fluxos necessários entre os centros de comando cerebrais e a periferia corporal, entre os órgãos de sentido e as sedes sensoriais, garantindo a memória, a consciência; enfim, todas as chamadas qualidades superiores" (Duarte, 2010: 320). A concepção de sistema nervoso permitia a conexão entre o físico e o moral, o hereditário e o adquirido, a fraqueza do sistema nervoso e a força de vontade.

Desse modo, afirma o antropólogo, “'força' e 'fraqueza' de fibras ou substâncias, 'força' e 'fraqueza' de sentimentos ou de caráter enovelam-se em intrincadas rendas de sentido e valorização" (Duarte, 20I0: 3I7-3I8). Ou, para condensar com as palavras de Henrique Roxo (I877-I969), um psiquiatra contemporâneo de Mário de Andrade, "a um sistema nervoso bem nutrido e desenvolvido deve corresponder uma personalidade nítida e acentuada" (apud Duarte, 20I0: 3I8).

Seguindo um raciocínio próximo ao de George M. Beard, o psiquiatra brasileiro Henrique Roxo (20I0) também apontava para uma correlação entre o grau de civilização de um país e a incidência de doenças nervosas em sua população. Sendo assim, quanto mais civilizado um país, mais preparados estarão seus nacionais para digerir a vida moderna em seus nervos (cf. Duarte, 20I0: 318). Nesse caso, podemos pensar a "civilização" como um estofo que possibilita aos indivíduos absorver os influxos da metrópole. Para o psiquiatra, no início do século XX o Brasil vivia, nas suas grandes cidades, uma propensão ao aparecimento de nervosos, fruto da imaturidade da nossa civilização, ou, em outros termos, de uma discrepância entre os influxos da vida moderna e a constituição nervosa dos indivíduos.

Com esse quadro em mente, é possível compreender as queixas e descrições de Mário de Andrade em cartas para os amigos como um processo de incorporação do diagnóstico de neurastenia aguda. É interessante observar que Mário de Andrade se referia constantemente ao fato de ter uma constituição 
nervosa fraca, ao mesmo tempo em que manifestava uma força de vontade férrea para continuar trabalhando e escrevendo.

\section{NERVOS FRACOS, VONTADE FORTE}

Mário de Andrade considerava a experiência do adoecimento em I9I3 tão marcante, que, além de conectá-la com sua opção pela literatura, teria provocado uma transformação em todo o seu ser. Em carta de I927 dirigida a Rui Ribeiro Couto, referindo-se a sua crise e ao processo de recuperação, contava: "um dia tive fome. Outro dia tive sono. E estou aqui. O mesmo de dantes não. Estou aqui o Mário de Andrade que vocês conhecem" (Andrade, I927). Considerava que nunca ficara completamente curado, pois "ficara sempre uma insônia e uma debilidade física que jamais corrigi inteiramente" (Andrade, I927). ${ }^{4}$

Nessa linha, ele passará a se identificar como um indivíduo "neurastênico", tendo que aprender a lidar com os seus "nervos" pelo resto da vida. Em carta endereçada a Carlos Drummond de Andrade, escrita em I4 de outubro de I 926, Mário de Andrade (2002: 248) observa: “O diabo é que qualquer doença me declancha uma neurastenia danada que está sempre preparadinha pra aparecer e contra a qual eu reajo todo dia”. É como se, na sua própria percepção, a neurastenia já fizesse parte dele, "porém" - como escreve em outra carta a Drummond - "aprendi a sarar" (Andrade, 2002: I I3).

Por sua vez, o próprio amigo passa a perceber Mário como um sujeito constantemente doente, mas que demonstra uma extrema força de vontade para não se deixar abater. ${ }^{5}$ Após saber de uma cirurgia a que fora submetido o escritor paulista, Drummond escreve de Itabira, no dia 7 de outubro de I926:

Uma operação é sempre uma coisa que assusta a gente, mesmo depois de acabada. Imagino o seu estado de espírito naturalmente em correspondência com o abatimento físico. Mas você, que é um bicho pra viver, deve estar vivendo com um gozo intenso esses dias de convalescença, não é? Tenho muita confiança na sua força. Por isso não preciso consolá-lo. E mesmo na dor invejo você. Sou fraco e covarde... (Andrade, 2002: 246).

Nesse sentido, é possível afirmar que a ideia de um sujeito doente, de nervos fracos, que, por outro lado, cultivava uma vontade forte, foi, cada vez mais, se enlaçando à identidade de Mário de Andrade.

\section{AUTOPSICOTERAPIA E REEDUCAÇÃO MORAL}

Mário de Andrade incorporou o diagnóstico de neurastenia e, por isso mesmo, desenvolveu maneiras de conviver com suas insuficiências de modo a neutralizá-las. Um bom exemplo desse exercício constante é o papel que atribui ao livro do médico Antonio Austregésilo. Segundo escreve a Ribeiro Couto, em carta de 20 de janeiro de I927, "quem me ensinou a dormir palavra que foi Austregésilo com a Cura dos Nervosos" (Andrade, I927). 
Antonio Austregésilo (I876-I960) era um reconhecido psiquiatra e hoje é considerado um dos principais introdutores da psicanálise no Brasil, bem como o autor dos primeiros estudos de neurologia no país. Em I 928 publicou A neurastenia sexual e seu tratamento e, em I9I6, A cura dos nervosos, o livro a que Mário de Andrade faz referência e que era dirigido a leigos, consistindo no que, nos dias atuais, chamaríamos de autoajuda. No caso, uma ajuda para que indivíduos se diagnosticassem como nervosos, soubessem que precisavam conviver com as manifestações dos seus nervos fracos e, finalmente, aprendessem técnicas que permitissem essa convivência.

Austregésilo era um exemplo de médico que portava a concepção de que um sistema nervoso fraco exigia do indivíduo uma vontade forte. Desse modo, considerava que a "educação moral" era o caminho, se não para a cura, para aprender a conviver com a doença. Daí o sentido de escrever um livro dirigido diretamente aos nervosos. Para ele, devido a sua constituição física, representada pelo sistema nervoso, alguns indivíduos estariam propensos, mais do que outros, a desencadear um processo de adoecimento nervoso. Na realidade, a rigor, ninguém se encontrava totalmente imune a uma crise nervosa, pois todas as pessoas estariam sujeitas a elementos detonadores, como o excesso de trabalho ou fortes comoções, as mesmas causas, aliás, a que Mário de Andrade atribuiu o fato de sua neurastenia "declanchar": estudo e trabalho excessivo e a morte do irmão, de "supetão" (Andrade, I927).

Para a transformação de um indivíduo nervoso em uma personalidade nítida e acentuada, com um sistema nervoso bem nutrido, Antonio Austregésilo (I943: 64) propunha que a "base está na educação moral", que consiste "ou na educação da vontade ou na boa diretriz da imaginação" (Austregésilo, I943: I59). Originando-se do consciente, a "vontade" é mais maleável e, assim, pode ser bem dirigida e cultivada. Contudo, por outro lado, essa intervenção pode provocar mais tensão no indivíduo nervoso, pois, nas palavras do autor, "os grandes esforços da vontade podem agravar a fobia, o escrúpulo, a dúvida ou a obsessão" (Austregésilo, I943: I59). Por sua vez, a "imaginação", menos maleável por ser originária do subconsciente, pode ser um caminho mais longo, porém mais seguro para o tratamento dos nervos. Desse modo, segundo Austregésilo (I943: I59),

Os preceitos da autossugestão baseiam-se especialmente em educar o subconsciente, ou melhor, a imaginação. [...] Os melhores momentos para praticar a autossugestão são a passagem da vigília para o sono, o despertar. O paciente procurará repetir para si, em forma de prece, as ideias sãs, contrárias às ideias doentes.

Além disso, a reeducação moral pode se dar por meio da psicoterapia, em que o médico pode explicar ao paciente seus "temores psíquicos". O tratamento moral consiste, fundamentalmente, "em raciocinar calmamente a propósito de cada comoção, escrúpulo, dúvida, ou fobia” (Austregésilo, I943: 65). A 
incorporação, por parte do paciente, do tratamento psicoterápico e também das técnicas de educação moral faz parte do que o médico propunha como autopsicoterapia (Austregésilo, I943: I49). Portanto, A cura dos nervosos, o livro lido por Mário de Andrade, consistia na consubstanciação da sua estratégia, pois, conforme o autor escreve no prefácio à primeira edição, "este livro é escrito para os doentes. A linguagem simples, despretensiosa e desataviada de noções científicas de gravidade, está indicando o fito do volume. [...] São conselhos úteis aos pacientes que, às vezes, sofrem muito sem saberem que o remédio está perto deles" (Austregésilo, I943: xxiii).

O livro consistia, portanto, em um caminho para a prática da autopsicoterapia, quando os "doentes podem por si, com a leitura atenta dos autores que tratem seriamente do assunto, curar-se inteiramente, ao menos muito melhorarem" (Austregésilo, I943: 66). A aproximação de Mário de Andrade em relação ao médico é explicitada ao escrever a Ribeiro Couto que aprendera a dormir por meio da leitura de A cura dos nervosos. No livro, diga-se de passagem, há um item intitulado "Insônia", no qual o autor estabelece algumas "regras indispensáveis", a começar que "o paciente, ainda que não possa dormir, deve ficar na cama" (Austregésilo, I943: 72). E sintetiza suas técnicas com a imagem segundo a qual "o sono é como um pombo: vem, se o não procurais; foge, se quereis pegá-lo" (Austregésilo, I943: 73).

Além do combate à insônia, as descrições que Mário de Andrade teceu sobre sua neurastenia nas cartas endereçadas aos amigos são muito próximas das descrições feitas por Austregésilo. Em carta de 29 de maio de I93 I, ele relata a Manuel Bandeira que "os médicos chegaram a não dar nada mais por mim, médicos de moléstias de nervos e o diabo. Não comia, não dormia e com os sintomas característicos de neurastenia negra, ódio de minha mãe, de todos os meus etc." (Andrade, 200I). De modo semelhante, no seu livro, Antonio Austregésilo apontava que seus "pacientes se acusam de indiferença pela família; sentem ausência íntima de amor dos esposos, filhos, e habitualmente contra as pessoas mais caras é que surgem as irritações, os ódios, os caprichos" (Austregésilo, I943: 62).

\section{TIO PIO: O OUTRO E O ESPELHO}

O médico pernambucano apontava também para a importância que uma pessoa próxima poderia vir a ter no processo de melhora do indivíduo nervoso. Para ele, "o paciente tem necessidade [...] de qualquer pessoa que lhe conquiste ascendência moral. Às vezes, a esposa, o irmão, o amigo, o sacerdote ou o clínico são elementos benéficos e indispensáveis para as melhoras e curas" (Austregésilo, I943: I49). No caso de Mário de Andrade, essa pessoa foi Pio Lourenço Corrêa. Conforme relata Gilda de Mello e Souza (2009: 19-20),

Em carta a Manuel Bandeira de 29 de maio de I93I, [Mário de Andrade] relata como foi o bom senso de um tio que o salvou: pegou nele, levou-o para a fazenda em Araraquara, deixou-o lá sozinho, aparecendo de tempos em tempos para 
saber se não estava precisando de nada e ia-se embora. Quando Mário voltou da fazenda, estava curado. É esta a primeira vez que a mão amiga de Pio Lourenço intervém no seu destino.

Nascido em I875, Pio Lourenço Corrêa era casado com Zulmira, prima de Mário de Andrade, além de ser extremamente próximo do seu pai, Carlos. A proximidade das famílias e a diferença de idade de quase 20 anos fizeram com que Mário sempre o tratasse como tio Pio. A relação entre os dois foi cultivada em uma troca de cartas que se iniciou em I9I7, aliás, o ano de estreia de Mário de Andrade na literatura, com seu Há uma gota de sangue em cada poema. Lembrando que o escritor estabelecia um nexo casual entre sua crise nervosa e o ato de versificar, não deixa de ser curioso o fato de que a correspondência tenha início com uma dedicatória de Mário no exemplar do livro endereçado a Pio, em que escreve: "Não sei se lhe será agradável saber que o seu tribunal é porventura um dos que mais temo" (cf. Guaranha, 2009: 34).

Ao lado disso, é de notar que a troca de cartas tem início meses após a morte do pai de Mário de Andrade, ocorrida em fevereiro de I9I7. Como observa Gilda de Mello e Souza (2009: I9), "dois acontecimentos familiares - duas mortes - foram decisivos na aproximação dessas duas pessoas tão diversas quanto a temperamento, concepção de vida, normas de conduta, preferências intelectuais e artísticas, ideias políticas". ${ }^{6}$ A primeira morte, ocorrida em I9I3, foi a do irmão mais novo de Mário de Andrade, que, como vimos, detonou sua crise nervosa, enquanto a segunda, a do pai, em I9I7, antecedeu a aproximação com o tio Pio.

As cartas prosseguiram até a morte de Mário de Andrade, em I945, formando um conjunto de quase 200 correspondências, em que tecem considerações de críticas literárias, comentários sobre a língua portuguesa, informações sobre expressões e costumes e solicitações de bibliografia. Depois de quase I5 anos de correspondência, em carta com data de i I de maio de I93I, ao saudar o tio por seu aniversário, Mário permite-se explicitar - em um "desabafo saído com toda a espontaneidade e que teve a enorme utilidade de me botar bem no meu lugar" - toda a importância que o amigo assumira em sua vida:

Embora seja muito mais fácil a gente contar por carta o que sente, sempre me prende agora um tal ou qual pudor de lhe dizer tudo o que o senhor representa pra mim, prefiro me guardar; tanto mais que a continuidade inalterável da minha maneira de ser pra com o senhor, prova bem que a sua amizade me honra e é utilíssima. Ora, me parece que dignificar e ser útil são as mais preciosas qualidades que um homem pode ter nesta nossa Terra. São qualidades suas pra comigo, qualidades que me fizeram buscá-lo, apesar de nossas diferenças de idade e de experiências de vida (Candido \& Mello e Souza, 2009: I82).

Uma vez reconhecida a amizade de um modo que não aparecera nas cartas até então, Mário de Andrade revela o modo pelo qual, como num castelo de cartas, sua identidade, feita de inconstâncias, se apoia na figura de firmeza moral que lhe representa o primo. Nas palavras de Mário de Andrade, 
Às minha 'loucuras', fantasias, curiosidades, a sua simplicidade sistematizada de ser deu maior paciência, mais precisão de fortificarem-se no estudo; à minha sensibilidade o senhor e sua vida trouxe novos lados, desconhecidos antes, por onde ela se experimentasse e enriquecesse; e finalmente à riqueza milionária das minhas fraquezas veio a sua belíssima e tão nobre atitude moral pôr freios, que uma educação muito imperfeita, mesmo com as tradições paterna e religiosa, creio que não seriam suficientes para refrear (Candido \& Mello e Souza, 2009: 182).

Para além da formação moral, Mário de Andrade contrapõe a figura do artista que ele é, com a do fazendeiro, norte da família, que o tio Pio representava.

Em vidas muito acidentadas e muito cheias de precariedade derivadas da curiosidade do mundo e da paixão por ele, como são no geral as vidas dos artistas e é esta minha, nada faz tanto bem, nada repõe a gente dentro da sua mais perfeita e sobrenatural finalidade que a presença dum homem de nobreza inflexível. A gente se garante nesse refúgio e cobra forças pra não derrapar definitivamente (Candido \& Mello e Souza, 2009: I82).

Nesse sentido, podemos sugerir que tio Pio foi para Mário de Andrade a pessoa que lhe conquistou "ascendência moral", conforme Austregésilo julgava necessário para um neurastênico. Contudo, não apenas de contraposição se constituía essa relação, pois ambos se encontravam na experiência comum da doença nervosa. Em carta de 29 de maio de I93 I, endereçada a Manuel Bandeira, Mário se referia ao primo como uma "espécie de neurastênico de profissão" (Moraes, 200I: 508). Seguindo essa trilha é possível analisar a relação entre Mário e Pio também a partir desse viés, dessa identificação na doença de "nervos".

Em texto sobre seu tio-avô paterno, Gilda de Mello e Souza (2009: I8) comenta essa faceta de Pio Lourenço:

estudos interrompidos, acomodações de carreira, epidemias e crises políticas, graves problemas familiares, tudo isso deixou marcas na sensibilidade exacerbada de Pio Lourenço e foi provavelmente responsável pelos mal-estares que o vão acompanhar pela vida afora: ciática, dor de estômago, depressões nervosas, temperamento progressivamente solitário.

Muitos anos depois da primeira crise de Mário de Andrade, já após I938 e sua saída do Departamento de Cultura de São Paulo, ou seja, já durante nova e profunda crise depressiva do escritor,7 o próprio Pio Lourenço fará referência a sua neurastenia. Então preocupado com as ideias suicidas manifestadas por Mário, na sua resposta de I 2 de abril de I940, Pio Lourenço recorda de antigo conselho de seu médico:

Eu conheço, por experiência, essas equimoses deprimente. Em Igı́o e IgII, ia quase sucumbindo, quando um médico amigo (o Dr. Carlos Botelho) me deu esta receita milagrosa: - 'Não se suicide, este é o único perigo a que V. está exposto; o resto passa'. E passou. E recaí. E passou de novo. E recaio frequentemente - mas lanço mão da receita que ainda conservo comigo: não me suicido... (Candido \& Mello e Souza, 2009: 337). ${ }^{8}$ 
Portanto, é com conhecimento tanto de causa quanto acerca da personalidade de Mário que tio Pio procura analisar sua nova crise: "dotado de nervos sensibilíssimos, V. recebe os choques e os encontrões da massa humana que o rodeia, e obstrui o caminho, com redobrada violência. A continuidade desses obstáculos, que a todos nos contraria, está fazendo mal a V" (Candido \& Mello e Souza, 2009: 337).

Feito o "diagnóstico", Pio já tem a prescrição e convida Mário para passar uns dias em sua fazenda, em Araraquara. Escreve:

Venha cá descansar, tomar fitina, comer ovos frescos, pescar lambaris, ler as Peregrinações, escrever artigos em ambiente perfumado de murtas e magnólias, rodeado dos 'pequenos barulhinhos que constituem o grande silêncio' e verá desaparecerem, na poeira das estradas do São Frco e do Matão, as equimoses subjetivas que mancham a alma e prejudicam a saúde do corpo (Candido \& Mello e Souza, 2009: 337).

Na sequência, é a seu médico, Carlos Botelho, que Pio Lourenço se refere e lembra dos seus conselhos para conviver com sua neurastenia, nos idos de I9Io. De qualquer modo, não parece demasiado forçado, fazer referência mais uma vez aos conselhos de Antonio Austregésilo (I943: I49), em seu livro de I9I6: "aos deprimidos urge repouso, superalimentação, permanência em lugar de campo ou praia, cercado de flores, de árvores, de paisagens alegres. O contato com a natureza é estímulo salutar para a vida e para a cura dos nervosos".

\section{A MODERNIDADE E SUAS DOENÇAS}

Como vimos, descrita pela primeira vez pelo médico norte-americano George M. Beard em momento de intensa expansão econômica de seu país, a "neurastenia" tornou-se uma doença própria da civilização, quando a constituição nervosa do indivíduo deixava de processar todos os estímulos gerados na vida das grandes cidades.

Beard comparou o sistema nervoso a uma máquina a vapor que produz energia capaz de acender lâmpadas em série. Nos Estados Unidos da segunda metade do século XIX, o rápido incremento das fábricas e dos meios de transporte, a imprensa periódica e a complexidade da educação e da ciência modernas teriam adicionado, seguindo a imagem, novas lâmpadas ao circuito, sem que o sistema nervoso fosse capaz de produzir a energia suplementar necessária. Neste caso, ocorreria a exaustão do sistema nervoso e o aparecimento da doença que o médico denominou neurastenia. Nesse sentido, a neurastenia articulava uma causa sociológica, o excesso de estímulos da vida moderna, a uma causa fisiológica, a incapacidade do sistema nervoso do indivíduo diagnosticado em processar esses estímulos.

Partindo de uma concepção de pessoa anterior a Freud, o corpo era visto em termos econômicos, em um balanço de receitas e despesas e com um sistema central produtor de energia que poderia ser sobrecarregado por um excesso 
de funções. Em seu livro de I88I, o neurologista nova-yorkino argumenta: "se um número extra de lâmpadas deve ser interposto no circuito, a potência do motor deve ser aumentada; do contrário, ou a luz das lâmpadas reduziria ou se apagaria" 9 (Beard, 20I5: 98). Similarmente, "o sistema nervoso do homem é o centro de fornecimento de força nervosa a todos os órgãos do corpo" Io (Beard, 20I5: 98). Assim, raciocina Beard (2015: 99), "quando novas funções são interpostas no circuito, como a civilização moderna constantemente exige que façamos, chega um momento em que [...] a quantidade de força é insuficiente para manter todas as lâmpadas ativamente acesas" "I.

A obra de George Beard ganhou legitimidade no meio médico, e a neurastenia tornou-se um consistente e popular diagnóstico de doença, ultrapassando as fronteiras dos Estados Unidos e da medicina para se tornar maneira influente de explicar a sensibilidade e as emoções na modernidade. Na expressão do próprio neurologista, a neurastenia tornou-se a "filosofia do nervosimo moderno" ${ }^{\text {12 }}$ (Beard, 20I5: 99).

Georg Simmel foi um dos leitores dos trabalhos de George Beard e, como apontou Leopoldo Waizbort (2000: 472) em As aventuras de Georg Simmel, o sociólogo alemão passou a explorar o tema dos "nervos enfraquecidos" e da "intensificação da vida nervosa" desde a segunda metade da década de I89o. Simmel também trabalhou dentro da concepção de um sistema nervoso que produz energia e da lógica de balanço entre receitas e dispêndios de energia. Contudo, havia uma diferença crucial. Beard imaginava duas saídas: ou, por um lado, o acréscimo de produção de energia por parte do sistema nervoso - por meio de hábitos higiênicos e períodos de descanso no campo - ou, por outro lado, a moderação nas atividades. Por sua vez, Simmel (2005: 582) introduziu uma nova variável na equação: um "órgão de proteção" proporcionado pela "reserva", atitude necessária para o morador da cidade se proteger contra uma profusão de novos estímulos. Para manter a imagem de um sistema elétrico pensada por Beard, em Simmel, a racionalidade e o dinheiro, discutidos mais extensamente em Filosofia do dinheiro (Simmel, I900), funcionariam como uma espécie de estabilizador que homogeneiza e amortece os estímulos. Ao tratar das grandes cidades e a vida do espírito, Simmel (2005: 58I) sugere que "a incapacidade [...] de reagir aos novos estímulos com uma energia que lhes seja adequada é precisamente aquele caráter blasé, que na verdade se vê em todo filho da cidade grande".

De certo modo, Mário de Andrade tratou sua neurastenia de uma forma mais próxima dos conselhos médicos de George Beard e de seus seguidores do que das reflexões desenvolvidas por Georg Simmel. Como vimos, ele costumava passar períodos de férias na chácara de seu tio Pio e a trocar sugestões de tratamento com ele - um "neurastênico profissional" -, além de seguir os conselhos de médicos que escreviam livros dirigidos a neurastênicos, como Antônio Austregésilo em seu A cura dos nervosos. Ir para a fazenda significava desligar as lâmpadas temporariamente. Por sua vez, em São Paulo (ou nas visitas 
ao Rio de Janeiro), Mário de Andrade se expunha aos mais radicais estímulos, sem nenhum mecanismo de proteção, sem adotar uma atitude blasé. Em vez de acionar um estabilizador das emoções, o escritor adotou a estratégia de simplesmente equilibrar a produção e o dispêndio de energia. Foi assim que lidou com sua neurastenia.

\section{CONSIDERAÇÕES FINAIS}

Foi na Fazenda Santa Isabel, em Araraquara, que Mário de Andrade se recuperou da crise nervosa de I9I3. Em seguida, passou a ser na chácara da Sapucaia, nas imediações da cidade de Araraquara, que passou muitas de suas férias. Nunca é demais notar, aliás, que foi lá, na chácara, esse lugar de "pequenos barulhinhos que constituem o grande silêncio", que foi escrito Macunaíma. De fato, Mário de Andrade costumava associar Sapucaia a "momentos poderosos de criação". No argumento que desenvolvi no artigo, pretendi salientar a ligação entre a vida no campo e a saúde dos nervos. Como Mário escreve ao tio em I3 de julho de I943, já em seus últimos e difíceis anos de vida:

É difícil imaginar o que Araraquara e sobretudo essa chácara representam pra mim. Refortalecimento do corpo, do espírito, férias felizes, refúgio disfarçado de lutas, de dúvidas, de sofrimentos. [...] Ninguém pode imaginar. Araraquara com a chacra da Sapucaia participam de minha vida e do que eu sou, quase tanto como esta rua Lopes Chaves (Candido \& Mello e Souza, 2009: 400).

Tanto a fazenda participava da vida de Mário e fazia parte do que ele era que, em mais de um momento e a mais de um amigo, confidenciou que a recuperação da crise nervosa de I9ı 3 na fazendo do tio Pio foi determinante para sua identidade de escritor. Na carta escrita a Manuel Bandeira, em 29 de maio de I93I, considerava que se reestabeleceu graças ao tio, mas completava:

Só que voltei poeta da fazenda. Sem nunca ter nem me preocupado em ler com prazer os poetas, já mesmo antes de ir pra fazenda, tinha dado em mim essa coisa esquisitíssima, talvez sintoma de loucura, uma mania de fazer versos. Foi assim (Moraes, 2001: 508).

Mesmo nas cartas, veículo por excelência para o exercício do decoro e para guardar o distanciamento, Mário de Andrade escrevia de forma transbordante e transparente, enfatizando sempre sua singularidade e não se preservando por meio do recurso da reserva. Vale lembrar que, para Simmel, a carta, especialmente a datilografada, era um meio pelo qual o indivíduo poderia se comunicar com o outro sem tornar explícitas as múltiplas variações do seu espírito no decorrer da escrita. O caminho escolhido por Mário de Andrade era o exato oposto, no qual o interlocutor - ao menos os amigos mais próximos não apenas tinham acesso aos detalhes das circunstâncias emocionais em que a carta fora redigida, como podiam, por meio dela, perceber as menores alterações de humor do seu missivista.

Hoje, quando a neurastenia já não é mais considerada um diagnóstico 
aceito pela comunidade médica, ela permanece sendo boa para pensar acerca da nossa condição moderna, ainda mais quando se vive sob a ameaça do SARS-Cov-2 e, em termos de política pública de saúde, estamos à mercê da dificuldade de o presidente e seus seguidores acessarem o mundo real. O cansaço, a insônia, a ansiedade e a irritabilidade rondam o cotidiano, e fica-se a perguntar, tal como faziam os neurastênicos, onde está o problema maior, se no excesso de estímulos do mundo lá fora, ou na falta de capacidade individual para lidar com tudo isso. Ao lado disso, o lockdown faz com que o distanciamento espacial teime em ser um isolamento social. Nestas circunstâncias, pensar no valor que Mário de Andrade atribuía às cartas e na forma em que ousava se exprimir por meio delas é uma forma de enxergar nos veículos de comunicação a distância - hoje podemos pensar nas redes sociais e nas facilidades que a tecnologia proporciona, quando podemos ouvir a voz e ver o outro - um caminho para quebrar o isolamento social e manter acesas as chamas das relações pessoais.

Recebido em 07/I I/2020 | Aprovado em 2I/05/202I

Robert Wegner é pesquisador da Fiocruz, onde atua no Programa de Pós-Graduação em História das Ciências e da Saúde, e professor do Departamento de Ciências Sociais da PUC-Rio. Graduado em ciências sociais pela UFPR e mestre e doutor em sociologia pelo Iuperj (atual Iesp/Uerj), recentemente realizou estudos de pósdoutorado na University of Illinois at Urbana-Champaign e publicou, em coautoria, "Race, science, and social thought in 2oth-century Brazil". 


\section{NOTAS}

I Este artigo incorpora e reelabora o texto publicado em 4 de maio de 2020 no Blog da Biblioteca Virtual do Pensamento Social, com o título "Mário de Andrade, suas cartas e nós: uma doença que não existe mais e uma doença dos nossos dias" e o trabalho "A doença nervosa de Mário de Andrade: neurastenia e identidade", que apresentei no XXVII Simpósio Nacional de História, realizado em Natal, em julho de 2013.

Agradeço ao CNPq, que financia minhas atividades de pesquisa mediante uma bolsa de Produtividade em Pesquisa (308I39/2019-4) e à Faperj, que, por meio de um Auxílio à Pesquisa Básica (E-26/210.493/2019), aporta recursos ao desenvolvimento da minha pesquisa sobre ciência e pensamento social no Brasil.

2 No original: "The body was always at risk, but a risk configured in idiosyncratic, physiological, multicausal, and contingent terms".

3 No original: "These theories communicated metaphorically the more abstract notion of disease entity as ideal type abstracted from its particular manifestations. A legitimate disease had both a characteristic clinical course and a mechanism".

4 Sob outro aspecto, a relação de Mário de Andrade com outra doença específica, a malária, foi tratada por Nísia Trindade Lima e André Botelho (2013). Embora explorando outros aspectos, minha reflexão foi motivada por esse texto.

5 Nesse ponto, sigo o argumento de Ricardo Benzaquen de Araújo, de que Mário de Andrade manifestava uma vontade forte. Por outro lado, distancio-me de sua interpretação, segundo a qual, ao contrário de Manuel Bandeira e sua tuberculose, "Mário [...] não parece converter os males físicos em uma condição, por mais que fale incessantemente deles" (Araújo, 20I9: 4I8). Meu argumento segue a direção inversa, afirmando que a "vontade forte" de Mário de Andrade é cultivada tendo como ponto de partida o reconhecimento de possuir "nervos fracos", de ser "neurastênico".

6 Mário de Andrade compararia sua reação diante das duas mortes em carta de 9 de maio de I939, endereçada a 
Sérgio Milliet. Após sofrer "horrivelmente" com a morte do pai, "logo me ergui de novo. Não é como o meu irmão que morreu e cuja morte até hoje me faz sofrer" (Duarte, I97I: 320).

7 Sobre essa nova e intensa crise de Mário de Andrade, ver Moraes (2005). Ao tratar dos últimos anos do autor, Eduardo Jardim elenca uma série de cartas em que o autor descreve aos próximos seu estado desde a sua saída do Departamento de Cultura de São Paulo e sua transferência para o Rio de Janeiro. Seu estado remete a muitas das características que descrevia ao abordar sua crise quando jovem.

8 Não é de surpreender que a referência ao combate à ideia de suicídio seja uma constante no livro de Austregésilo (I943: 30), que, a certa altura, escreve: "Nenhuma ideia de moléstia deve conduzir-nos ao desejo de morte ou do suicídio; estes anelos ou são interjeições censuráveis, ou fraqueza da alma humana, ou egoísmo. Devemos viver e ter coragem para as estações da existência, isto é, inverno e verão, primavera e outono, que sintetizem os períodos de bom e maus humor, da coragem e dos condenáveis desânimos".

9 No original: "If an extra number of lamps should be interposed in the circuit, then the power of the engine must be increased; else the light of the lamps would be decreased, or give out".

Io No original: "The nervous system of man is the centre of the nerve-force supplying all the organs of the body".

I I No original: "and when new functions are interposed in the circuit, as modern civilization is constantly requiring us to do, there comes a period, sooner or later, varying in different individuals, and at different times of life, when the amount of force is insufficient to keep all the lamps actively burning".

I2 No original: "the philosophy of modern nervousness".

\section{REFERÊNCIAS}

Andrade, Carlos Drummond de. (2002). Carlos e Mário: correspondência entre Carlos Drummond de Andrade e Mário de 
Andrade: 1924-I945. Rio de Janeiro: Bem-Te-Vi Produções Literárias.

Andrade, Mário de. (200I) [I93I]. Carta de Mário de Andrade a Manuel Bandeira. In: Moraes, Marcos Antonio de (Org.). Correspondência: Mário de Andrade \& Manuel Bandeira. 2 ed. São Paulo: Edusp.

Andrade, Mário de. (1927). Carta de Mário de Andrade a Rui Ribeiro Couto. Fundo Rui Ribeiro Couto, Fundação Casa de Rui Barbosa.

Araújo, Ricardo Benzaquen de. (20I9). Um grão de sal: autenticidade, felicidade e relações de amizade na correspondência de Mário de Andrade com Carlos Drummond. In: Felgueiras, Carmen; Jasmin, Marcelo \& Veneu, Marcos (orgs.). Zigue-zague: ensaios reunidos (I977-2016). Rio de Janeiro/São Paulo: Editora PUC-Rio/Editora Unifesp.

Austregésilo, Antonio. (I943). A cura dos nervosos. 8 ed. Rio de Janeiro: Editora Guanabara.

Beard, Georg Miller. (2015) [I88I]. American nervousness its causes and consequences: a supplement to Nervous Exhaustion (Neurasthenia). Facsimile by Forgotten Books. New York: G. P. Putnam's Sons.

Candido, Antonio \& Mello e Souza, Gilda de (orgs.). (2009). Pio \& Mário: diálogo da vida inteira. A correspondência entre o fazendeiro Pio Lourenço Corrêa e Mário de Andrade, I9I7I945. Rio de Janeiro/São Paulo: Ouro sobre Azul/Sesc SP.

Duarte, Luiz Fernando. (20Io). O nervosismo como categoria nosográfica no começo do século XX. História, Ciências, Saúde - Manguinhos, I7/suppl.2, p. 313-326.

Duarte, Paulo. (I97I). Mário de Andrade por ele mesmo. São Paulo: Edart.

Guaranha, Denise. (2009). Nota explicativa. In: Candido, Antonio \& Mello e Souza, Gilda de (orgs.). Pio \& Mário: diálogo da vida inteira. A correspondência entre o fazendeiro Pio Lourenço Corrêa e Mário de Andrade, I9I7-I945. Rio de Janeiro/São Paulo: Ouro sobre Azul/Sesc SP.

Lima, Nísia Trindade \& Botelho, André. (2013). Malária como doença e perspectiva cultural nas viagens de Carlos Chagas e Mário de Andrade à Amazônia. História, Ciências, Saúde - Manguinhos, 20/3, p. 745-763. 
Mello e Souza, Gilda de. (2009). O arcaico e o moderno: história de uma amizade. In: Candido, Antonio \& Mello e Souza, Gilda de (orgs.). Pio \& Mário: diálogo da vida inteira. A correspondência entre o fazendeiro Pio Lourenço Corrêa e Mário de Andrade, I9I7-I945. Rio de Janeiro/São Paulo: Ouro sobre Azul/Sesc SP, p. I5-3I.

Miceli, Sergio. (2009). Mário de Andrade: a invenção do moderno intelectual brasileiro. In: Schwarcz, Lilia \& Botelho, André (orgs.). Um enigma chamado Brasil: 29 intérpretes e um país. São Paulo: Companhia das Letras.

Moraes, Eduardo Jardim de. (2005). Mário de Andrade: a morte do poeta. Rio de Janeiro: Civilização Brasileira.

Moraes, Marcos Antonio de (org.). (200I). Correspondência: Mário de Andrade \& Manuel Bandeira. 2 ed. São Paulo: Edusp. Rosenberg, Charles. (2002). The tyranny of diagnosis: specific entities and individual experience. Milbank Quarterly, 8o/2, p. 237-26o.

Roxo, Henrique de Brito Belford. (2010). Nervosismo. História, Ciências, Saúde - Manguinhos, I7/suppl.2, p. 654-668. [Publicado originalmente em Arquivos Brasileiros de Psiquiatria, Neurologia e Medicina Legal, Rio de Janeiro, n.I-2, p.73-106, I916]

Simmel, Georg. (2005) [1903]. As grandes cidades e a vida do espírito. Trad. Leopoldo Waizbort. Mana, II/2.

Waizbort, Leopoldo. (2000). As aventuras de Georg Simmel. São Paulo: Editora 34.

Zorzanelli, Rafaela Teixeira. (2010). Neurastenia. História, Ciências, Saúde - Manguinhos, I7/suppl.2, p. 43I-446. 


\section{MÁRIO DE ANDRADE, SUAS CARTAS E NÓS: UMA DOENÇA QUE NÃO EXISTE MAIS E A DOENÇA DOS NOSSOS DIAS}

\section{Resumo}

Aborda a identificação de Mário de Andrade (I893-I945) com o diagnóstico médico da "neurastenia" e argumenta que o escritor afirmou sua "vontade forte" ao se reconhecer portador de "nervos fracos", a principal característica dessa doença. O médico norte-americano Geoge M. Beard (I839-I883) que, em I869, formulou o diagnóstico de neurastenia, atribuiu sua ocorrência aos tempos modernos e ao excesso de estímulos nervosos nas grandes cidades. A partir dessa reflexão histórica, ensaio uma conexão entre a experiência existencial de Mário de Andrade e a nossa experiência diante de uma doença nova, a Covid-I9, fortemente conectada ao capitalismo globalizado e à devastação ambiental e que, se não é uma doença de ordem psiquiátrica, provoca desafios a nossa estabilidade emocional. Assim como Mário foi um exímio escritor de cartas, o texto salienta a importância dos meios contemporâneos de comunicação para a manutenção de laços de sociabilidade e de amizade em tempos difíceis.

\section{MÁRIO DE ANDRADE, HIS LETTERS AND US: A DISEASE THAT NO LONGER EXISTS AND THE DISEASE OF OUR TIMES}

The article explores the identification of Mário de Andrade (1893-1945) with the medical diagnosis of "neurasthenia", and argues the Brazilian writer affirmed his "strong will" from the recognition of having "weak nerves", the trait of this disease. The American physician Geoge M. Beard (I839I883) formulated the diagnosis of neurasthenia in I869. He attributed its occurrence to modern times and large cities. Based on the historical reflection, I suggest a link between Mário de Andrade's existential experience and our experience in the face of a new disease. The Covid-I 9 is connected to globalized capitalism and environmental devastation, and it is a disease that challenges our emotional stability. Just as Mário was a good letter writer, I argue that social media can serve to cultivate friendship in difficult times.
Palavras-chave

Neurastenia;

Covid-I9;

Mário de Andrade;

identidade;

doença.

\section{Keywords}

Neurasthenia;

Covid-I 9;

Mário de Andrade;

identity;

disease. 